\title{
Prevalence of falls in elderly people: a population based study
}

\section{SUMMARY}

INTRODUCTION: The occurrence of falls is related to a complex interaction of risk factors, aggravated by aging. This research aimed to investigate the occurrence of falls in the elderly, as well as to identify the risk factors for this event.

METHODS: A cross-sectional, population-based study conducted in a municipality in the extreme south of Brasil. Probabilistic sampling was used, the sample unit being the census tracts. Data were collected through home interviews. The research was approved by the research ethics committee.

RESULTS AND DISCUSSION: This study was performed using a sample of 211 elderly individuals. The prevalence of falls was $28.9 \%$ (95\% $\mathrm{Cl} 22.8$ to 35.0). $(P=0.01)$, living alone $(p=0.04)$, self-perception of regular or poor health $(p=0.03)$, and obesity $(p=0.01)$.

CONCLUSIONS: We found that approximately one in three elderly individuals fell in the last year.

KEYWORDS: Aged. Accidental falls. Public health. Epidemiology. Risk factors.

\section{INTRODUCTION}

A fall episode is defined as an unintentional change of body position resulting in contact with the ground or another lower level that is not the consequence of an intrinsic event or great danger ${ }^{1}$. The Ministry of Health considers falls among elderly individuals an important public health problem, given its high incidence and its possible consequences to health, such as injury, disability, institutionalization, and death ${ }^{2}$. Fall episodes involving the elderly are more frequent than health and social issues and can have consequences on the family environment, on the economic aspect, as well as on the physical and mental health of individuals ${ }^{3}$.
In Brasil, data from the Brazilian Institute of Geography and Statistics (IBGE) ${ }^{4}$ show that the population with age equal to or greater than 60 years is around $25,964,619$ inhabitants. The total number of hospitalizations due to falls among elderly Brazilians, in hospital units of the Unified Health System (SUS), between 2005 and 2010, was 399,681, with a cost reported by the Hospital Admission Authorization (AIH), a mandatory document that enables all hospital admissions in the SUS, of $\mathrm{R} \$ 464,874,275.91$ in the same period ${ }^{5}$.

A Brazilian study, whose data collection was carried out between 1996 and 2012, pointed out that 66,876 deaths were recorded due to falls and 941,923

DATE OF SUBMISSION: 15-May-2019

DATE OF ACCEPTANCE: 11-Jun-2019

CORRESPONDING AUTHOR: Miss Letícia Almeida

Rua Visconde de Paranaguá 102, Rio Grande, RS, Brasil - CEP 96201-900

Tel: +55 (53) 3233.8800

E-mail: leticiamsalmeida@hotmail.com 
hospitalizations resulting from it in elderly individuals aged 60 years or more ${ }^{6}$. The aging process increases risk factors and comorbidities, especially of chronic-degenerative diseases ${ }^{7}$. As a consequence, for a significant portion of individuals, these pathologies will bring some degree of disability, with decreased physical capacity and restrictions to autonomy and independence $\mathrm{e}^{2.8}$.

Falls are related to a complex interaction of risk factors that are aggravated with aging 9 . The main risk factors can be classified as a) biological agents, such as age, gender, and race, associated to changes due to aging; b) behavioral, related to human actions, emotions or daily choices that are potentially modifiable; c) environment, which includes the interaction of physical conditions of individuals and the environment that surrounds them; d) socioeconomic factors, such as inequality of work/income, education, housing without conditions of sanitation, limited access to health care and social assistance in priority areas and lack of resources in the community ${ }^{8.9}$.

Despite the importance of the issue, in view of its frequency, deleterious effects on health, and its cost to the public health system, there is still a lack of population-based studies in the country on this topic. Therefore, the objective of this study was to analyze the occurrence of falls and identify groups at risk among elderly patients of a municipality in the extreme south of Brasil.

\section{METHODS}

This is a population-based cross-sectional study that is part of a larger project called "Saúde da população riograndina". This project was developed in 2016 with the objective of evaluating health aspects of the adult population ( $\geq 18$ years) living in the city of Rio Grande, in the state of Rio Grande do Sul, Brasil.

The inclusion criteria were: age greater than or equal to 65 years and residing in the urban area of the municipality of Rio Grande. Individuals institutionalized in nursing homes, hospitals, and prisons and those with physical and/or intellectual disabilities that prevented them from answering the questionnaire were excluded. The research project was submitted to and approved by the Health Research Ethics Committee (Cepas) of the Federal University of Rio Grande (FURG), under process number 20/2016. Further methodological details about the study can be found in another publication ${ }^{10}$.
The sampling process occurred in two stages; the first stage was the selection of census sectors, and the second, the selection of households. A total of 72 census sectors were systematically selected out of the 293 of the urban area of the municipality. To select the census sectors, a list was drawn up of all households in descending order according to the monthly income of the head of the family. Soon after, 711 households were selected in proportion to the size of the sector. Out of these households, 676 were sampled (95\% of the total), and in 164 of them, there was at least one elderly individual (aged 65 years or more), which corresponded to $24 \%$ of the households sampled in this research. Since in some households there were more than one elderly individuals, the study sample comprised 211 individuals. The sample studied ( $\mathrm{N}=211)$ had a power of $80 \%$ to detect prevalence ratios equal to or greater than 2.0, with a frequency of exposed ranging from $20 \%$ to $80 \%$.

The dependent variable in this study was the occurrence of a fall in the past 12 months, with the following question, "Since $<$ MONTH $>$ of last year, have you suffered a fall at home or on the street?". The independent variables analyzed were: age (65 to $69 / 70$ to $79 / 80$ or more); gender (male/female); skin color (white/other); marital status (married/single, separated or widowed); reside alone (no/yes); years of formal education (0 to 8/greater than or equal to 9); index of goods into terciles (poorest/intermediary/ richest); physical activity during leisure time (no/yes); self-perception of health (excellent, very good, good/ regular, bad); stress into terciles (lowest/intermediary/ Highest); arterial hypertension (yes/no); arthritis or rheumatism (no/yes); chronic back pain (no/yes), and obesity (no/yes).

The instrument was a questionnaire standardized for the study. The index of goods variable was created from 11 items on household characteristics and presence of domestic goods by means of principal component analysis, in which the first component that explained more than $30 \%$ of the variability of all the others was extracted. Physical activity during leisure time was measured by the long version of the International Physical Activity Questionnaire (IPAQ), validated for use in Brasil ${ }^{11}$. Stress was measured by the Scale of Perceived Stress ${ }^{12}$. Data on hypertension and arthritis or rheumatism were collected from the self-reported medical diagnosis. Chronic back pain was considered as a complaint of pain for more than three consecutive months. 
Obesity was defined as a body mass index (BMI) $\geq$ $30 \mathrm{~kg} / \mathrm{m}^{2}$, from self-reported weight and height.

The data were collected from April to July 2016 by interviewers trained for this purpose, by means of face to face home interviews. The data was input to EpiData 3.1 software, and the analysis was performed in the Stata statistical package, version 11.2. Univariate analysis was made by means of absolute and relative frequencies. The bivariate and multivariate analyses were carried out through Poisson regression, taking into account the effect of the sampling design. The prevalence ratios (PR) with 95\% confidence intervals (95\% CI) were presented. For the multivariate analysis, we built a five-level model of analysis, namely: gender, skin color, marital status, and living alone (first level); formal education, and index of goods (second level); physical activity, self-perception of health, and stress (third level); hypertension, arthritis or rheumatism, chronic back pain, and obesity (fourth level). The level of statistical significance was $5 \%$ for two-tailed tests.

\section{RESULTS}

This study was conducted using a sample of 211 elderly individuals. The occurrence of falls was $28.9 \%$ (95\% CI 22.8 to 35.0). The effect of the sample design found was 0.96 (intraclass correlation coefficient = 0.014). The average age of the sample was 73 years ( $\mathrm{SD}=6.6$ ), ranging from 65 to 96 years of age.

Table 1 shows the descriptive data of the sample studied in this research. It included mostly women (62.1\%), of white skin color (85.3\%), married (51.2\%), with up to eight years of formal education (66.7\%), who did not practice physical activity (70.3\%) and who had hypertension (57.8\%). As for the other comorbidities, a fifth (20.1\%) were obese, approximately $30 \%$ had arthritis or rheumatism, and approximately one fourth (25.6\%) reported chronic back pain. The self-perception of health was assessed as regular or bad by half of the sample (49.3\%).

The occurrence of falls over the past year was $28.9 \%$ (95\% CI 22.8 to 35.0 ). The occurrence varied from $9.1 \%$ in elderly individuals who perceived their health as excellent, very good or good, to $42.5 \%$ in those with obesity, and $43.2 \%$ in those who lived alone. For the other groups, the occurrence of falls ranged between $20 \%$ and $40 \%$, except for the male gender, which was $17.5 \%$ (Table 2).

Table 2 also presents the gross and adjusted associations between the occurrence of falls in accordance with the characteristics investigated. We found, in the gross analysis, that the occurrence of falls was more frequent among females $(\mathrm{p}=0.01)$, those who live alone

TABLE 1. DESCRIPTION OF THE CHARACTERISTICS FROM THE ELDERLY SAMPLE OF RIO GRANDE, RS, 2016 $(N=211)$.

\begin{tabular}{|c|c|c|}
\hline Variable & $N$ & $\%$ \\
\hline \multicolumn{3}{|l|}{ Age range (years) } \\
\hline 65 to 69 & 77 & 36.5 \\
\hline 70 to 79 & 99 & 46.9 \\
\hline$\geq 80$ & 35 & 16.6 \\
\hline \multicolumn{3}{|l|}{ Gender } \\
\hline Male & 80 & 37.9 \\
\hline Female & 131 & 62.1 \\
\hline \multicolumn{3}{|l|}{ Skin color } \\
\hline White & 180 & 85.3 \\
\hline Others & 31 & 14.7 \\
\hline \multicolumn{3}{|l|}{ Marital status } \\
\hline Married & 108 & 51.2 \\
\hline Single, separated, widowed & 103 & 48.8 \\
\hline \multicolumn{3}{|l|}{ Lives alone } \\
\hline No & 167 & 79.1 \\
\hline Yes & 44 & 20.9 \\
\hline \multicolumn{3}{|l|}{ Formal education (years) } \\
\hline 0 to 8 & 140 & 66.7 \\
\hline$\geq 9$ & 70 & 33.3 \\
\hline \multicolumn{3}{|l|}{ Index of property (tertiles) } \\
\hline 1 (lower) & 85 & 40.3 \\
\hline 2 (intermediate) & 52 & 24.6 \\
\hline 3 (higher) & 74 & 35.1 \\
\hline \multicolumn{3}{|l|}{ Physical activity during leisure } \\
\hline No & 147 & 70.3 \\
\hline Yes & 62 & 29.7 \\
\hline \multicolumn{3}{|l|}{ Self-perception of health } \\
\hline Excellent/very good/good & 107 & 50.7 \\
\hline Regular/bad & 104 & 49.3 \\
\hline \multicolumn{3}{|l|}{ Stress (tertiles) } \\
\hline 1 (lower) & 87 & 41.8 \\
\hline 2 (intermediate) & 72 & 34.6 \\
\hline 3 (higher) & 49 & 23.6 \\
\hline \multicolumn{3}{|l|}{ Hypertension } \\
\hline No & 89 & 42.2 \\
\hline Yes & 122 & 57.8 \\
\hline \multicolumn{3}{|l|}{ Arthritis or rheumatism } \\
\hline No & 149 & 70.6 \\
\hline Yes & 62 & 29.4 \\
\hline \multicolumn{3}{|l|}{ Chronic back pain } \\
\hline No & 157 & 74.4 \\
\hline Yes & 54 & 25.6 \\
\hline \multicolumn{3}{|l|}{ Obesity } \\
\hline No & 157 & 79.7 \\
\hline Yes & 40 & 20.3 \\
\hline Total & 211 & 100.0 \\
\hline
\end{tabular}


TABLE 2. DISTRIBUTION OF FALLS ACCORDING TO THE CHARACTERISTICS OF THE ELDERLY IN RIO GRANDE, RS, $2016(N=211)$.

\begin{tabular}{|c|c|c|c|c|c|}
\hline \multirow[t]{2}{*}{ Variable } & \multirow[t]{2}{*}{$\%$ falls } & \multicolumn{2}{|c|}{ Unadjusted analysis } & \multicolumn{2}{|c|}{ Adjusted analysis } \\
\hline & & $\mathrm{PR}(95 \% \mathrm{Cl})$ & P-value & $\mathrm{PR}(95 \% \mathrm{Cl})$ & P-value \\
\hline Age range (years) & & & 0.38 & & 0.33 \\
\hline 65 to 69 & 23.4 & 1.00 & & 1.00 & \\
\hline 70 to 79 & 33.3 & $1.43(0.86 ; 2.36)$ & & $1.45(0.89 ; 2.36)$ & \\
\hline$\geq 80$ & 28.6 & $1.22(0.65 ; 2.35)$ & & $1.20(0.64 ; 2.24)$ & \\
\hline Gender & & & 0.01 & & 0.01 \\
\hline Male & 17.5 & 1.00 & & 1.00 & \\
\hline Female & 35.9 & $2.05(1.19 ; 3.55)$ & & $1.98(1.16 ; 3.37)$ & \\
\hline Skin color & & & 0.36 & & 0.16 \\
\hline White & 27.8 & 1.00 & & 1.00 & \\
\hline Others & 35.5 & $1.28(0.75 ; 2.18)$ & & $1.41(0.87 ; 2.30)$ & \\
\hline Marital status & & & 0.19 & & 0.44 \\
\hline Married & 25.0 & 1.00 & & 1.00 & \\
\hline Single, separated, widowed & 33.0 & $1.32(0.87 ; 2.01)$ & & $0.81(0.46 ; 1.40)$ & \\
\hline Lives alone & & & 0.02 & & 0.04 \\
\hline No & 25.2 & 1.00 & & 1.00 & \\
\hline Yes & 43.2 & $1.72(1.11 ; 2.66)$ & & $1.60(1.03 ; 2.49)$ & \\
\hline Formal education (years) & & & 0.28 & & 0.57 \\
\hline 0 to 8 & 31.4 & $1.29(0.81 ; 2.08)$ & & $1.14(0.72 ; 1.82)$ & \\
\hline$\geq 12$ & 24.3 & 1.00 & & 1.00 & \\
\hline Index of property (tertiles) & & & 0.04 & & 0.17 \\
\hline 1 (lower) & 38.8 & $1.69(1.02 ; 2.80)$ & & $1.52(0.87 ; 2.66)$ & \\
\hline 2 (intermediate) & 21.2 & $0.92(0.47 ; 1.79)$ & & $0.91(0.47 ; 1.75)$ & \\
\hline 3 (higher) & 23.0 & 1.00 & & 1.00 & \\
\hline Physical activity during leisure & & & 0.20 & & 0.26 \\
\hline No & 31.3 & $1.39(0.84 ; 2.29)$ & & $1.32(0.81 ; 2.13)$ & \\
\hline Yes & 22.6 & 1.00 & & 1.00 & \\
\hline Self-perception of health & & & 0.01 & & 0.03 \\
\hline Excellent/very good/good & 9.1 & 1.00 & & 1.00 & \\
\hline Regular/bad & 39.4 & $2.11(1.26 ; 3.53)$ & & $1.78(1.06 ; 3.00)$ & \\
\hline Stress (tertiles) & & & $0.14^{*}$ & & $0.85^{\star}$ \\
\hline 1 (lower) & 24.1 & 1.00 & & 1.00 & \\
\hline 2 (intermediate) & 29.2 & $1.21(0.68 ; 2.14)$ & & $1.04(0.62 ; 1.76)$ & \\
\hline 3 (higher) & 36.7 & $1.52(0.88 ; 2.64)$ & & $1.05(0.59 ; 1.87)$ & \\
\hline Hypertension & & & 0.05 & & 0.58 \\
\hline No & 21.4 & 1.00 & & 1.00 & \\
\hline Yes & 34.4 & $1.61(1.00 ; 2.60)$ & & $1.18(0.66 ; 2.11)$ & \\
\hline Arthritis or rheumatism & & & 0.54 & & 0.62 \\
\hline No & 27.5 & 1.00 & & 1.00 & \\
\hline Yes & 32.3 & $1.17(0.70 ; 1.97)$ & & $0.85(0.45 ; 1.61)$ & \\
\hline Chronic back pain & & & 0.38 & & 0.36 \\
\hline No & 27.4 & 1.00 & & 1.00 & \\
\hline Yes & 33.3 & $1.22(0.78 ; 1.90)$ & & $0.82(0.52 ; 1.27)$ & \\
\hline Obesity & & & 0.01 & & 0.01 \\
\hline No & 24.2 & 1.00 & & 1.00 & \\
\hline Yes & 42.5 & $1.76(1.15 ; 2.68)$ & & $1.70(1.16 ; 2.51)$ & \\
\hline
\end{tabular}

PR: Prevalence Ratio; $95 \% \mathrm{Cl}$ : confidence interval of $95 \%$. ${ }^{*}$-value of the test for linear trend 
$(p=0.02)$, the poorest $(p=0.04)$, those with a perception of poor or regular health $(p=0.01)$, hypertensive patients $(p=0.05)$, and obese $(p=0.01)$. After adjustment for confounding factors, only females $(p=0.01)$, living alone $(\mathrm{p}=0.04)$, regular or poor self-perception of health $(p=0.03)$, and obesity $(p=0.01)$ remained statistically significant associations (Figure 1). The other variables were not significantly associated with the outcome.

\section{DISCUSSION}

The aim of this study was to investigate the association between falls of elderly individuals and demographic, socioeconomic, behavioral, and health characteristics. We found that almost one in every three elderly individuals experienced falls over the past year. The most affected groups were women, individuals who live alone, with a worse perception of health, and obese.

The frequency of falls found in this study (28.9\%) resembled a few national and international studies. A study conducted in several municipalities of Brasil ${ }^{13}$, with a sample of 6,624 individuals, reported an occurrence of $27.6 \%$ (95\% CI: 26.5-28.7). A survey with 683 elderly individuals in Montes Claros, MG, pointed to an occurrence of $28.3 \%$ in the last 12 months $^{14}$. At an international level, individuals older than 65 years in the United States of America had 28.7\% of occurrence of falls in $2014^{15}$. In the English Longitudinal Study of Aging, the weighted occurrence for the past two years was $28.4 \%{ }^{16}$.

The greater occurrence of falls among females is consistent in the literature. Both Brazilian ${ }^{3,13,17}$ and foreign studies ${ }^{16.18}$ presented this finding. The causes cited to justify the greater occurrence of falls among elderly women are increased bone fragility in relation to men, higher occurrence of some chronic diseases, greater exposure to domestic activities, and physical-functional decline ${ }^{15,19,20}$.

Elderly people who lived alone had a higher risk of falls. The hypothesis presented in some studies point is that elderly individuals are more exposed to a greater number of activities (at home and in other places) ${ }^{20}$, and that this age group presents a greater likelihood of disability relating to basic and instrumental activities ${ }^{21}$ and, therefore, greater vulnerability in tasks that would produce a greater number of situations that present a risk for falls ${ }^{22}$.

An association was found between the perception of regular or poor health and the likelihood of falls. The self-perception of health is considered an important indicator of health, widely used in health research and surveys, both due to its easy applicability and its low cost compared to other more complex methods. It is also a predictor of morbidity and mortality: people with restrictions and limitations develop dissatisfaction, which is reflected in this criteria ${ }^{14,23,24}$. However,

FIGURE 1. PREVALENCE RATIO OF FALL-RELATED FACTORS THAT WERE STATISTICALLY SIGNIFICANT IN THE ADJUSTED ANALYSIS. RIO GRANDE, RS, 2016 ( $N=211)$.

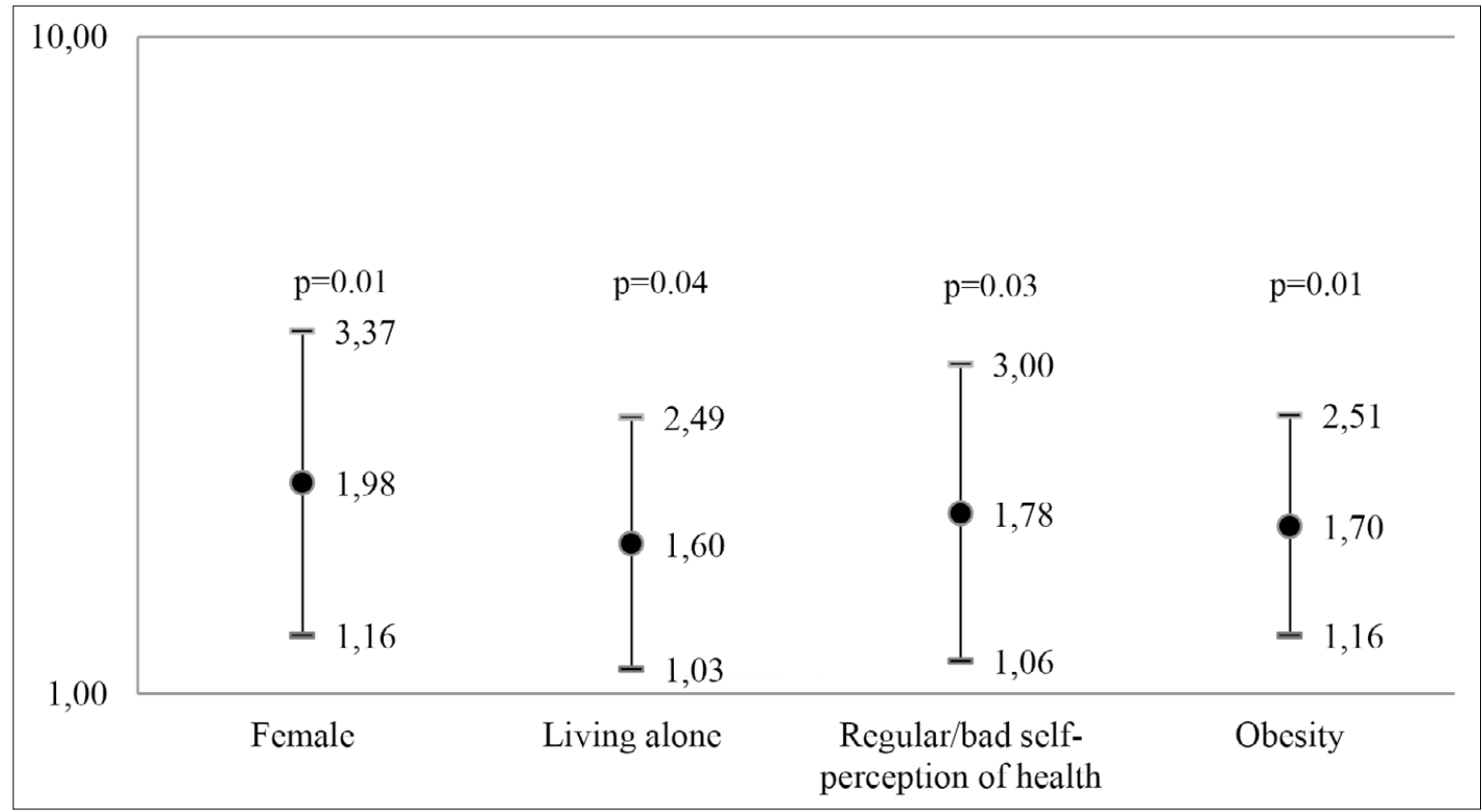


a worsened perception of health can be the result of episodes of falls, so it can suffer the influence of reverse causality bias.

As to the association with obesity, in line with other studies ${ }^{13.25}$, it is justified by the postural imbalance as a result of excess weight and fat accumulation in the abdominal region. Furthermore, obese individuals have a lower amplitude of movement and greater torque in the ankle joint to maintain the balance ${ }^{13.25}$. This finding shows the importance of interventions aiming at weight maintenance or reduction among the elderly since this is a modifiable risk factor ${ }^{13.25}$. It stands out, however, that some studies found no association between BMI and falls ${ }^{9.26}$.

The results of this study demonstrated a lack of association between the presence of arthritis or rheumatism and chronic back pain with fall events in the population assessed. The literature indicates that musculoskeletal disorders, which result in joint stiffness and pain and chronic inflammatory processes, are linked to instability in walking and balance ${ }^{20,27-29}$. Still, the increase in chronic diseases and the occurrence of severe pain are concomitant to the loss of functional capacity, an increase of immobility and physical dependence are associated with a greater likelihood of falls in men and women ${ }^{16}$. However, it is worth noting that elderly individuals with physical limitations (such as arthritis, or rheumatism, or back pain) are less exposed to risk situations due to their conditions.

It is important to point out some limitations of this study. This research is part of a larger project, which was not intended only for this research object, nor only to elderly subjects. As a result, the sample size was not very large, which may have affected the accuracy of the study. However, it is worth noting that all associations with PR greater or equal to 1.60 were detected as statistically significant. Perhaps there was not enough power to detect the association with individuals of lower socioeconomic level ( $P R=1.52 ; p=0.17)$. It should also be noted that we did not investigate the characteristics of the fall episode, such as, if it was the first time it happened, where it happened, possible sequelae, such as fracture or hospitalization, and use of medications. Thus, we can only make inferences on the frequency of falls and their associated factors.

Due to the increase in the elderly population in our country, and acknowledging that several changes are needed in the care and follow-up of this population, identifying risk factors and factors associated with falls is of paramount importance to reduce morbidity and mortality. This study is representative of the local population and can be extrapolated to other groups of elderly individuals, so these data can be used as a tool for health managers and professionals to plan for public policies that allow for the organization of the health services care offered to the elderly population. We recommend that other studies include the rural population of the municipality and survey the health care costs from elderly people who suffer falls. Finally, interventional studies that evaluate strategies for preventing this situation are compelling and scarce.

\section{CONCLUSION}

We found an occurrence of $28.9 \%$ of falls among elderly individuals with a mean age of 73 years. The significant risk factors were female $(p=0.01)$, living alone $(p=0.04)$, regular or poor self-perception of health $(p=0.03)$, and obesity $(p=0.01)$.

\section{Conflict of interest}

The authors declare there are no conflicts of interest.

\section{Acknowledgments}

SCD has a scholarship on research productivity from the CNPq. LMSA has a scientific initiation scholarship from CNPq.

\section{Funding}

Fapergs (Fundação de Amparo à Pesquisa do Estado do Rio Grande do Sul) - Programa Primeiros Projetos ARD/PPP 2014, under number 16/2551-0000359-9.

\section{Approval by the research ethics committee}

Health Research Ethics Committee (Cepas) of the Federal University of Rio Grande (FURG), under process number 20/2016.

\section{Contribution of the authors}

LMSA conceived the study, collected the data, and wrote the article. RDM and SCD analyzed the data, critically reviewed the article, and oversaw the work. All authors approved the final version of the manuscript. 


\section{RESUMO}

INTRODUÇÃO: A ocorrência de quedas está relacionada a uma interação complexa de fatores de risco, agravados com o envelhecimento. Esta pesquisa teve como objetivo investigar a ocorrência de quedas em idosos, bem como identificar os fatores de risco a esse evento.

METODOlogia: Estudo transversal, de base populacional, conduzido em município do extremo sul do Brasil. Utilizou-se amostragem probabilística, sendo a unidade amostral os setores censitários. A coleta de dados ocorreu por meio de entrevistas domiciliares. A pesquisa foi aprovada por comitê de ética.

RESULTADOS E DISCUSSÃo: Este estudo foi realizado utilizando amostra de 211 idosos. A ocorrência de quedas foi de 28,9\% (IC95\% 22,8 a 35,0). Mantiveram associação estatística, após ajuste para fatores de confusão, apenas sexo feminino ( $p=0,01)$, morar sozinho ( $p=0,04)$, autopercepção da saúde regular ou ruim $(p=0,03)$ e obesidade $(p=0,01)$.

CONCLUSÕES: Verificou-se que aproximadamente um em cada três idosos sofreu queda no último ano.

PALAVRAS-CHAVE: Idoso. Acidentes por quedas. Saúde pública. Epidemiologia. Fatores de risco.

\section{REFERENCES}

1. Ansai $H$, Glisoi SFN, Oliveira T, Soares AT, Cabral KN, Sera CTN, et al. Revisão de dois instrumentos clínicos de avaliação para predizer risco de quedas em idosos. Rev Bras Geriatr Gerontol. 2014;17(1):177-89.

2. Brasil, Ministério da Saúde. Envelhecimento e saúde da pessoa idosa. Cadernos de Atenção Básica nº 19. Brasília: Ministério da Saúde; 2006. p.67-70.

3. Araújo SP, Maia IRP, Vieira JNL, Soares KVBC, Dias RS. Características e ocorrências das quedas em idosos residentes em São Luís, Maranhão. Rev Pesq Saúde. 2014;15(3):331-5.

4. Instituto Brasileiro de Geografia e Estatística. 2013. Projeção da população do Brasil por sexo e idade: 2000-2060. [cited 2017 Jul 31]. Available from <http://www.ibge.gov.br/home/estatistica/populacao/projecao_da_populacao/2013/default_tab.shtm>

5. Barros IFO, Pereira MB, Weiller TH, Anversa ETR. Internações hospitalares por quedas em idosos brasileiros e os custos correspondentes no âmbito do Sistema Único de Saúde. Rev Kairós. 2015;18(4):63-80.

6. Abreu DROM, Novaes ES, Oliveira RR, Mathias TAF, Marcon SS. Internação e mortalidade por quedas em idosos no Brasil: análise de tendência. Ciênc Saúde Colet. 2018;23(4):1131-41

7. Siqueira FV, Facchini LA, Piccini RX, Tomasi E, Thumé E, Silveira DS, et al. Prevalência de quedas em idosos e fatores associados. Rev Saúde Pública. 2007;41(5):749-56.

8. Caberlon IC, Bós AIG. Diferenças sazonais de quedas e fraturas em idosos gaúchos. Ciênc Saúde Colet. 2015;20(12):3743-52.

9. Prato SCF, Andrade SM, Cabrera MAS, Dip RM, Santos HG, Dellaroza MSG et al. Frequency and factors associated with falls in adults aged 55 years or more. Rev Saude Publica. 2017:51(10):37.

10. Dumith SC, Paulitsch RG, Carpena MX, Muraro MFR, Simões MO, Machado KP, et al. Planejamento e execução de um inquérito populacional de saúde por meio de consórcio de pesquisa multidisciplinar. Sci Med. 2018;28(3):ID30407.

11. Matsudo S, Araújo T, Matsudo V, Andrade D, Andrade E, Oliveira LC, et al. Questionário Internacional de Atividade Física (IPAO): estudo de validade e reprodutibilidade no Brasil. Rev Bras Ativ Fís Saúde. 2001;6(2):5-18.

12. Reis RS, Hino AA, Añez CR. Perceived stress scale: reliability and validity study in Brazil. J Health Psychol. 2010;15(1):107-14.

13. Siqueira FV, Facchini LA, Silveira DS, Piccini RX, Tomasi E, Thumé E, et al. Prevalence of falls in elderly in Brazil: a countrywide analysis. Cad Saude Publica. 2011;27(9):1819-26.

14. Carneiro JA, Ramos GCF, Barbosa ATF, Vieira ÉDS, Silva JSR, Caldeira AP. Quedas em idosos não institucionalizados no norte de Minas Gerais: prevalência e fatores associados. Rev Bras Geriatr Gerontol. 2016;19(4):613-25.

15. Bergen $G$, Stevens MR, Burns ER. Falls and fall injuries among adults aged $\geq 65$ years - United States, 2014. MMWR Morb Mortal Wkly Rep. 2016;65(37):993-8
16. Gale CR, Cooper C, Aihie Sayer A. Prevalence and risk factors for falls in older men and women: the English Longitudinal Study of Ageing. Age Ageing 2016;45(6):789-94

17. Rodrigues IG, Fraga GP, Barros MBA. Quedas em idosos: fatores associados em estudo de base populacional. Rev Bras Epidemiol. 2014;17(3):705-18.

18. Büchele G, Becker C, Cameron ID, König HK, Robinovitch S, Rapp K. Predictors of serious consequences of falls in residential aged care: analysis of more than 70,000 falls from residents of Bavarian nursing homes. I Am Med Dir Assoc. 2014;15(8):559-63.

19. Perracini MR, Ramos LR. Fatores associados a quedas em uma coorte de idosos residentes na comunidade. Rev Saúde Pública. 2002;36(6):709-16.

20. Soares WIS, Moraes AS, Ferriolli E, Perracini MR. Fatores associados a quedas e quedas recorrentes em idosos: estudo de base populacional. Rev Bras Geriatr Gerontol. 2014;17(1):49-60.

21. Nunes JD, Saes MO, Nunes BP, Siqueira FCV, Soares DC, Fassa MEG, et al. Indicadores de incapacidade funcional e fatores associados em idosos: estudo de base populacional em Bagé, Rio Grande do Sul. Epidemiol Serv Saude. 2017;26(2):295-304.

22. Rodrigues RAP, Silva AF, Fabricio-Wehbe SCC, Diniz MA, Fhon JRS. Quedas em idosos domiciliados e sua associação com as atividades da vida diária. Rev Enferm. 2015;23(5):589-95.

23. Almeida ST, Soldera CLC, Carli GA, Gomes IR, Resende TL. Análise de fatores extrínsecos e intrínsecos que predispõem a quedas em idosos. Rev Assoc Med Bras. 2012;58(4):427-33.

24. Dantas EL, Brito GEG, Lobato IAF. Prevalência de quedas em idosos adscritos à estratégia de saúde da família do município de João Pessoa, Paraíba. Rev APS. 2012;15(1):67-75

25. Costa AGS, Costa FBC, Oliveira ARS, Silva VM, Araújo TL. Ocorrência de quedas e índice de massa corporal em idosos. Rev Enferm. 2013;21(4):508-14.

26. Thaler-Kall K, Peters A, Thorand B, Grill E, Autenrieth CS, Horsch A, et al. Description of spatio-temporal gait parameters in elderly people and their association with history of falls: results of the population-based cross-sectional KORA-Age study. BMC Geriatr. 2015;15:32.

27. Abreu DROM, Azevedo RCS, Silva AMC, Reiners AAO, Abreu HCA. Fatores associados à recorrência de quedas em uma coorte de idosos. Ciênc Saúde Colet. 2016;21(11):3439-46

28. Gomes ECC, Marques APO, Leal MCC, Barros BP. Fatores associados ao risco de quedas em idosos institucionalizados: uma revisão integrativa. Ciênc Saúde Colet. 2014;19(8):3543-51.

29. Menezes RL, Bachion MM. Estudo da presença de fatores de riscos intrínsecos para quedas, em idosos institucionalizados. Ciênc Saúde Colet. 2008;13(4):1209-18. 